\title{
A revision of the genus Sindora (Fabaceae, Detarioideae) in Peninsular Malaysia and Singapore
}

\author{
L.M. $\mathrm{Choo}^{1} \&$ K.M. $\mathrm{Ngo}^{2}$ \\ ${ }^{1}$ Singapore Botanic Gardens, National Parks Board, \\ 1 Cluny Road, 259569 Singapore \\ choo_le_min@nparks.gov.sg \\ ${ }^{2}$ Asian School of the Environment, Nanyang Technological University, \\ 50 Nanyang Avenue, 639798 Singapore
}

\begin{abstract}
Sindora Miq. is a genus of large legume trees found mainly in tropical and subtropical forests from southern China, continental Southeast Asia, and West and Central Malesia. A revision of Sindora in Peninsular Malaysia and Singapore is presented with updated descriptions and distributions. The data are derived from a comprehensive study of herbarium specimens from Peninsular Malaysia and Singapore, together with field observations of individuals growing in natural populations in Singapore. Five species are recorded from Peninsular Malaysia. Four species are recorded from Singapore, all of which also occur in Peninsular Malaysia. Sindora velutina Baker, only recently recorded for Singapore but at the same time noted to be presumed nationally extinct, is reported here as rediscovered. Lectotypes of Sindora siamensis Teijsm. ex Miq. and Sindora velutina are designated here. A second step lectotype is designated for Sindora wallichii Benth. New global-level conservation assessments are proposed for Sindora echinocalyx Prain, Sindora siamensis and Sindora wallichii Benth., while provisional national-level conservation assessments for each species are also reported. Four species of Sindora in Peninsular Malaysia are reported as Least Concern both globally and within Peninsular Malaysia; Sindora siamensis is reported as Least Concern globally but is presumed Nationally Extinct in Peninsular Malaysia. In Singapore all four species of Sindora are reported as Critically Endangered.
\end{abstract}

Keywords. Conservation assessments, lectotypification, Leguminosae, overlooked species, taxonomic update

\section{Introduction}

Sindora Miq. is a genus of legume trees (Fabaceae; bean family) of 20-22 species from the subfamily Detarioideae that can be found from southern China, continental Southeast Asia, and West and Central Malesia, with the centre of diversity in Borneo, and one species in West Central Africa (de Wit, 1949; Chen et al., 2010). As part of ongoing Flora of Singapore and Flora of Peninsular Malaysia projects, a comprehensive revision of Sindora for the region has been carried out. The last revision of the genus for the region was published in Flora Malesiana by Hou (1996). Here we include new localities, new morphological observations, nomenclatural corrections and conservation assessments. 
The genus Sindora is easily recognised by its distinctive pods, with spines originating from modified glands, and arillate seeds (de Wit, 1949). However, the individual species of Sindora are much less easily distinguished from one another. In the early descriptions of Sindora species in Peninsular Malaysia, much confusion reigned over the application of names to particular species. The first account of Sindora in Peninsular Malaysia was written by Prain (1897) in King's Materials for a Flora of the Malay Peninsula, where the species Sindora wallichii Benth. (as 'wallichiana'), Sindora echinocalyx Prain, and Sindora intermedia Baker were included. This was followed by Ridley's treatment in the Flora of the Malay Peninsula (Ridley, 1922), where he synonymised Sindora echinocalyx under Sindora wallichii, and maintained Sindora intermedia as a separate species. This taxonomic confusion was addressed by Symington (1938), where the differences between Sindora echinocalyx and Sindora wallichii were highlighted and specimens were correctly cited, while Sindora intermedia was synonymised under Sindora wallichii. A comprehensive revision of the genus in Southeast Asia was carried out by de Wit (1949), based on the specimens in Herbarium Bogoriense and in the Rijksherbarium in Leiden, but it was only in 1972 that Whitmore's account of the genus in Tree Flora of Malaya (Whitmore, 1972) provided updates to the distribution of species within Peninsular Malaysia along with a usable taxonomic key. The most recent taxonomic account, by Hou (1996), was based on de Wit's revision of the genus, but with changes to nomenclature, citations and typifications. Here we provide a comprehensive account of Sindora in Peninsular Malaysia and Singapore.

\section{Materials and methods}

Sindora specimens from KEP and SING were studied, along with images of type specimens from various herbaria available on JSTOR Plants (https://plants.jstor.org/). New localities were discovered during recent fieldwork in Singapore in Bukit Timah Nature Reserve, which has Singapore's largest contiguous patch of primary rainforest (Ho et al., 2019). Descriptions are generally made from herbarium specimens but the colours of fresh material are provided where available to facilitate field identification. The descriptions include data from specimen labels. Flower measurements were made from rehydrated herbarium specimens. Locality information for all species was obtained from georeferenced specimens from KEP and SING.

Species identifications were generally made from mature material, as the leaves of seedlings, saplings and the water shoots of mature trees often have a morphology different from that of mature leaves (de Wit, 1949). The leaves of Sindora seedlings, saplings and water shoots are usually larger in size and are pubescent on the underside and along the leaflet margins. As they mature, the leaves become sparsely puberulous or glabrous, and this is typical of the leaves found together with flower or fruit at the crown of the tree. In the absence of mature leaves from the crown, given the height of mature trees, a combination of fallen fruits or flowers together with leaflets picked 
off the forest floor can be more reliable for identification than leaves collected from a nearby seedling or sapling.

To construct the distribution maps, a total of 1014 raw records of localities of the five species were gathered from herbarium specimens in KEP, SING and records exported from the Global Biodiversity Information Facility (GBIF; GBIF. org, 6 August 2020a,b,c,d,e), which consisted of digitised specimen information from A, AAU, K, L, MO, P, U, US and WAG. The records from GBIF were individually verified by checking that the associated image of the specimen matched the species identification, while the identifications of specimens from KEP and SING have been verified in person. The GPS coordinates assigned to the specimens were checked to ascertain that they matched the locality described on the label. Records without precise locality information, such as those listing only the state or country of collection, were discarded. Records which were not yet georeferenced were assigned as precise a GPS coordinate point as possible based on the locality information on the sheet. A total of 696 clean and verified data points were obtained for the five species. Maps were generated from all clean and verified data points regardless of whether the species was extant in the location to show the entire range of the species.

Conservation assessments were carried out at three different levels, firstly on a global level for Sindora echinocalyx, S. siamensis Teijsm. ex Miq. and S. wallichii, followed by provisional assessments on a national level for Peninsular Malaysia and Singapore respectively. Sindora coriacea and S. velutina Baker have recent IUCN Red List Assessments and are not re-assessed here. IUCN Red List Categories and Criteria v. 3.1 (IUCN, 2012) and Guidelines for Using the IUCN Red List Categories and Criteria (IUCN Standards and Petitions Committee, 2017) were used to assign the conservation status for the global assessment and the national-level assessment for Peninsular Malaysia. Georeferenced localities of each species were imported into GeoCAT (geocat.kew.org; Bachman et al., 2011) to calculate the Area of Occupancy (AOO) and Extent of Occurrence (EOO). Categories for the national-level conservation assessment for Singapore were assigned based on the criteria listed in Davison et al. (2008).

\section{Taxonomic treatment}

Sindora Miq., Fl. Ned. Ind., Eerste Bijv. 2: 287 (1861); Prain, J. Asiat. Soc. Bengal, Pt. 2, Nat. Hist. 66(1): 201 (1897); Ridley, Fl. Malay Penins. 1: 637 (1922); de Wit, Bull. Jard. Bot. Buitenzorg, ser. 3, 18: 5 (1949); Whitmore, Tree Fl. Malaya 1: 270 (1972); Larsen et al., Fl. Thailand 4(1): 98 (1984); Corner, Wayside Trees Mal., ed. 3, 1: 445 (1988); Hou in Hou et al., Fl. Males., ser. 1, Spermat. 12(2): 691 (1996); Hou, Tree Fl. Sabah \& Sarawak 3: 166 (2000). - TYPE: Sindora sumatrana Miq.

Echinocalyx Benth. in Bentham \& Hooker, Gen. P1. 1(2): 584 (1865). - TYPE: No species described. 
Medium to large unarmed trees; bole generally straight, columnar and with slightly raised rings around the girth; branching off from the upper half of the tree, in saplings branching off at irregular intervals; buttresses present or absent; bark grey-brown to dark brown to blackish, with pale lichen-like patches, smooth to slightly cracked to finely lenticellate. Stipules intrapetiolar, foliaceous, unequal and broadly falcate, pubescent, caducous or persistent. Leaves compound, paripinnate, (2-)3-6-jugate, rachis furrowed when dry, petiolules short, grooved and drying dark brown to black. Leaflets opposite, coriaceous, base rounded to obtuse, upper surface generally glabrous, rarely puberulous to finely pubescent; lower surface glabrous, puberulous or pubescent on both the leaflet underside and the midrib, midrib raised, reticulations present on both the upper and lower leaflet surfaces, with crateriform glands on both the tip of the midrib and on one (rarely both) sides of the base of the leaflet on the thickened marginal vein. Inflorescence paniculate, both terminal and axillary, consisting of one or more long, upright flowering rachis(es) with side branches emerging at regular intervals along the length of the flowering rachis, entire inflorescence covered with short tomentose hairs which become increasingly dense towards the apex of the inflorescence. Flowers strongly zygomorphic with short receptacles and pedicels. Sepals 4, unequal, lanceolate to elliptic, slightly imbricate but separating slightly even in young buds, outer surface densely pubescent to tomentose, armed or unarmed, inner surface densely covered with long adpressed hairs. Petal 1, usually fleshy, exserted from or nestled within the largest and adaxial-most sepal of the flower, outer surface partly glabrous and partly densely tomentose, inner surface glabrous, margins villous to tomentose. Stamens generally 10, diadelphous with a 9+1 arrangement, the adaxialmost free and reduced to a staminode, the other 9 united into a sheath-like bundle for a short length at the base, densely villous at the base but becoming glabrous towards the tip of the filaments, with the two longest stamens at both ends of the bundle; anthers dorsifixed and dehiscing by longitudinal slits along their lengths, those of the two longest stamens elliptic or oblong, those of the other smaller stamens present or sometimes absent, smaller and more rounded. Ovary shortly stipitate, flattened and pubescent, sometimes armed with short spines or warts visible beneath the pubescence; style long and slender, black or brown when dry; stigma small and capitate. Fruit a flattened, elliptic, rounded or ovate two-valved dehiscent pod, slightly inflated at the centre around the seeds, with sharp spines that sometimes exude a clear resin, rarely unarmed; surface beneath the spines smooth or warty, veins raised, pubescent in young pods and becoming glabrous over time; with 1-3(-7) arillate seeds. Seeds flattenedellipsoid in shape, surface dark or black, smooth with fine horizontal cracks across the surface, pleurogram absent, with a large fleshy red or yellow aril at the base.

Distribution. A genus of 20-22 species restricted to southern China, continental Southeast Asia, and West and Central Malesia bounded by Wallace's Line, except for one species found in tropical West Central Africa.

Etymology. Sindur, a vernacular name for this genus in Sumatra. 
Uses. Sindora, which is commercially known as Sepetir, has timber which can be used for indoor furnishings such as cabinets, panelling and doors. Species with heavier wood are used for heavy construction such as bridges and poles; several species produce resin or wood-oil, which is used for making paints and varnishes and used in traditional medicine (Sosef, 1993).

Taxonomy. The genus Echinocalyx was described from a flowering specimen from Malacca by Bentham in 1865. In the protologue, Bentham had already questioned if Echinocalyx was the same as Sindora, although he was not able to confirm it because the flowers of Sindora were not described in Miquel's protologue of the genus. However, two years later in 1867, Bentham (1867) reduced Echinocalyx to a synonym of Sindora after viewing an authentic specimen from Miquel.

\section{Key to Sindora species of Peninsular Malaysia and Singapore}

1a. Leaflets broadly elliptic, apex strongly emarginate, midrib on the lower surface with a gland located 1-3 mm away from the tip of the leaflet; calyx warty with small spines at the apex ............................................................. 3. S. siamensis

1b. Leaflets falcate, elliptic, obovate or lanceolate, apex if emarginate only very slightly notched at the tip, midrib on the lower surface with a gland at the very tip of the leaflet; calyx never warty, either unarmed or armed with spines ..... 2

2a. Lower surface of leaflets densely pubescent or tomentose, distinctly velvety or rough to touch; leaves 4-6-jugate; rachis of young leaflets, inflorescence and stipe of pods densely tomentose with reddish brown hairs 4. S. velutina

2b. Lower surface of leaflets puberulous to glabrescent to glabrous, may be slightly rough like fine sandpaper but never velvety; leaves (2-)3-4-jugate; rachis of young leaflets puberulous to glabrous, inflorescence or stipe of pods pubescent to tomentose with golden brown hairs 3

3a. Lower surface of leaflets glabrous or only sparsely puberulous at the base in mature leaflets except for the midrib which is usually puberulous; calyx and pods unarmed 1. S. coriacea

3b. Lower surface of leaflets entirely puberulous with small, thin adpressed or strigose hairs in mature leaflets; calyx and pods armed 4

4a. Leaflets without raised reticulations above, upper surface smooth and glossy and shining; calyx armed only on the upper half or on the very tip of the bud, with small spines less than $1 \mathrm{~mm}$ long 5. S. wallichii

4b. Leaflets with raised reticulations above, upper surface not glossy; calyx armed all over the exterior of the bud with long soft spines which are brittle when dry, spines up to $2 \mathrm{~mm}$ 2. S. echinocalyx 
1. Sindora coriacea (Baker) Prain J. Asiat. Soc. Bengal, Pt. 2, Nat. Hist. 66(1): 206 (1897); Ridley, Fl. Malay Penins. 1: 637 (1922); de Wit, Bull. Jard. Bot. Buitenzorg, ser. 3, 18: 30, f. 5 (1949); Whitmore, Tree Fl. Malaya 1: 271 (1972); Larsen et al., Fl. Thailand 4(1): 98 (1984); Hou in Hou et al., Fl. Males., ser. 1, Spermat. 12(2): 697 (1996); Loo \& Tan, Gard. Bull. Singapore 49: 99 (1997); Turner, Gard. Bull. Singapore 47: 310 (1997 ['1995']); Hou, Tree Fl. Sabah \& Sarawak 3: 169 (2000); Chong et al., Checkl. Vasc. Pl. Fl. Singapore 80, 136, 211 (2009). - Afzelia coriacea Baker in Hooker, Fl. Brit. India 2(5): 275 (1878). - TYPE: Peninsular Malaysia, Malacca, 1865, A.C. Maingay 2611 (also as 'Kew Distribution 566') (lectotype K [K000780071], designated by de Wit, Bull. Jard. Bot. Buitenzorg, ser. 3, 18: 33 (1949)). (Fig. 1C \& 3).

Tree up to $37 \mathrm{~m}$, dbh up to $100 \mathrm{~cm}$, usually unbuttressed, rarely with steep and thick buttresses up to $1.8 \mathrm{~m}$. Stipules tiny, even in seedlings, c. $4 \mathrm{~mm}$ long, caducous. Leaves 3-4-jugate, rarely 2-3-jugate; rachis minutely puberulous to glabrous, (2-)5.5-11.5 cm long; petiole 2-4(-5.5) cm long; petiolules 3.5-8 $\mathrm{mm}$ long, minutely puberulous or sparsely pubescent. Leaflets smooth on both upper and lower surfaces, elliptic to ovate to broadly falcate, asymmetric with the midrib curved, $4.5-14.7 \times 2.1-8.1 \mathrm{~cm}$, increasing in size up the rachis with the largest pair of leaflets at the tip, apex bluntly acute to acuminate, rarely obtuse and sometimes slightly emarginate at the very tip; upper surface glabrous with the midrib slightly sunken and widening at the base; lower surface usually glabrous in mature leaflets but occasionally sparsely puberulous at the base of the leaflet, and more visibly pubescent in young leaflets, midrib minutely puberulous to glabrous; thickened marginal vein usually glabrous but sometimes puberulous especially in saplings; reticulations clear and raised on both the upper and lower surfaces; one gland present on the tip of the midrib on the lower surface, another present on the thickened marginal vein close to the base of the leaflet. Inflorescence with long and stout flowering rachises, (12.5-)16-38.5 × 3-9 $\mathrm{cm}$, side branches irregularly curved, appearing soft and flexible; bracts not seen, caducous; bracteoles ovate or lanceolate, $2-2.5 \mathrm{~mm}$ long, pubescent on both surfaces, caducous, seen only on very small buds and shed thereafter; pedicels $3.5-5.5 \mathrm{~mm}$ long; receptacle short, 1-1.5 mm; buds obovoid, 5-8.5 $\times 3.5-4 \mathrm{~mm}$ when mature just before anthesis. Sepals 4-5(-6.8) $\times 1.5-3 \mathrm{~mm}$, outer surface greenish yellow and unarmed, inner surface rusty velvety. Petal with a well-defined hood at the top tapering to lower half with the edges inrolled at the sides, almost forming a tube, 5.9-6.5 × 1.4-2.2 mm, outer surface glabrous at the top and down the middle, densely pubescent at the sides and the lower half of the petal, margin along the top densely villous to sparsely villous. Stamens 9-10, united in basal portion 1.9-2.2 $\mathrm{mm}$ long, two longest filaments green, rest of the filaments white, generally $3.4-11.5 \mathrm{~mm}$ long; anthers yellow, the two largest anthers $2-2.3 \times 0.7-1 \mathrm{~mm}$, the others $1-1.5 \times 0.6 \mathrm{~mm}$. Ovary semicircular, densely pubescent around the edges and glabrous in the centre, surface unarmed and maroon-brown to black when dry, 2.5-3 × 1.5-2 mm, stipe $1.5 \mathrm{~mm}$ long; style glabrous, $9.5-10.5 \mathrm{~mm}$. Pods elliptic to round to ovate, surface unarmed or with few slightly raised warts, dark reddish brown to black in colour, 4.4-10 × 3.3-6.2 cm, stipe 3-9 mm, beak 4-12 mm. Seeds 1-3, aril chestnut-brown, semi-circular or trapezoid, 1.4-2 × 1.3-1.4 $\times 0.9 \mathrm{~cm}$, 

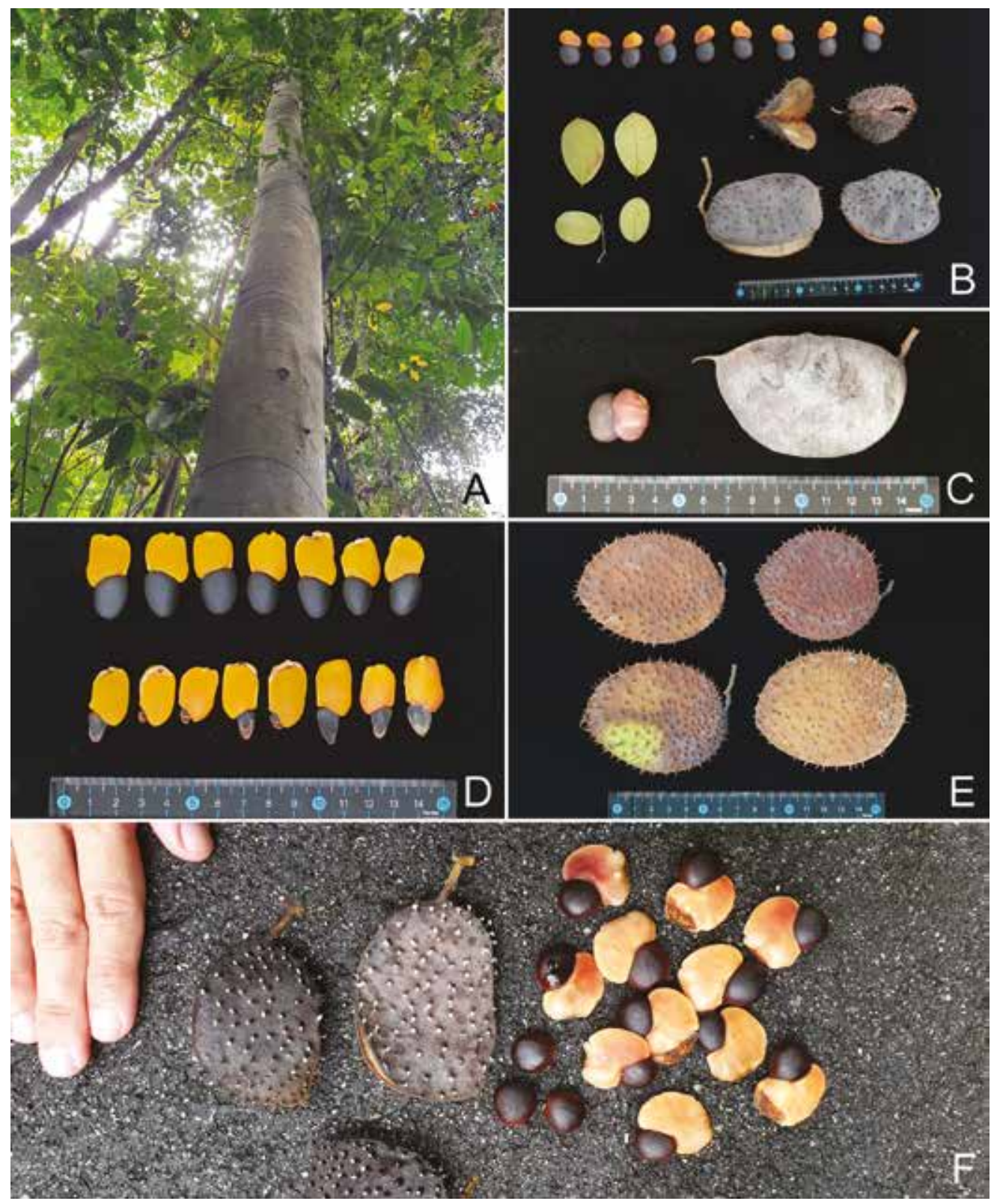

Fig. 1. Trunk, fruit and seeds of various Sindora species. A. Trunk of Sindora wallichii Benth., showing the smooth bark and the slightly raised rings around the girth. B. Fallen leaflets, seeds and pods of Sindora wallichii. C. Seed and the spineless pod of Sindora coriacea (Baker) Prain. D. Seeds of Sindora velutina Baker, showing the squarish and bright yellow aril. E. Pods of Sindora velutina. F. Pods and seeds of Sindora siamensis Teijsm. ex Miq. (cultivated at Singapore Botanic Gardens). A from Choo et al. SING2019-655, B from Choo et al. SING2019943, C from Choo et al. SING2019-840, D \& E from Choo et al. SING2019-944. (Photos: L.M. Choo). 
seed 1.9-2.5 × 1.4-1.6 × 0.8-0.9 cm, surface smooth and black but becoming maroon towards the centre of the seed.

Distribution. Peninsular Thailand, Peninsular Malaysia, Sumatra (East Coast), Singapore, Borneo (Sabah and Kalimantan). The species is widespread and has been recorded from all states in Peninsular Malaysia, as well as from Singapore.

Ecology. Sindora coriacea is found scattered but widespread in forests at low altitudes on non-inundated sandy and often leached soils, on hillsides and near streams, usually up to $300 \mathrm{~m}$, although a collection from Penang Hill, Penang, Peninsular Malaysia, was made at $600 \mathrm{~m}$. In Singapore, Sindora coriacea is found in areas of primary growth in the lowland tropical rainforests.

Etymology. Latin, coriaceus = coriaceous, leathery; referring to the leathery texture of the leaflets of this species.

Vernacular names. Sepetir, Sepetir licin, Sepetir minyak (Malay).

Uses. This species is an important source of sepetir timber because it is common in many areas and also because of its large size. While the wood is valued for its attractive patterns, it is reportedly soft and non-durable, hence it is used mainly for indoor construction and furniture and ornamental cabinets. Small amounts of wood-oil are also known to be collected for medicinal use.

Provisional IUCN conservation assessment. Least Concern (LC) globally (Barstow, 2019a). The species is provisionally assessed here to be of Least Concern (LC) in Peninsular Malaysia where it is widespread. However, in Singapore, Sindora coriacea is provisionally assessed here to be nationally Critically Endangered (CR/D), based on the criteria in Davison et al. (2008), as there are likely to be fewer than 250 mature trees and these are found only in primary forests or as remnant individuals in mature secondary forests which are fragmented habitats in Singapore.

Specimens examined. PENINSULAR MALAYSIA: Kedah: Sungai Lalang F.R., Compt. 25, 20 Jul 1960, Kochummen 94262 (SING [SING0229993]). Kelantan: Gua Musang, Sg. Brok, 17 Jun 1967, Ng FRI 5517 (KEP [KEP155608]); Kuala Lebir, 1905, Haviland s.n. (SING [SING0229967]). Malacca: Ayer Panas, 15 Jun 1966, Ng FRI 1180 (SING [SING0230143]); ibidem, 7 Apr 1918, Abu CF 2080 (SING [SING0229992, SING0230004]); Chabau [Chabow], 18 Sep 1885, Alvin's Collector s.n. (SING [SING0230002]). Negeri Sembilan: Jelebu, Pasoh F.R., 19 Oct 1976, Mat Asri FRI 25710 (KEP [KEP90625]); ibidem, 5 Sep 1983, Ang FRI 27819 (KEP [KEP196790]). Pahang: Kemansul F.R., 24 May 1962, Mohzam Husain 99594 (SING [SING0229971]); Kuala Lipis, 31 May 1918, Sulaiman CF 1289 (SING [SING0229977]); Lipis, Taman Negara, Merapoh, 2 Oct 2014, Chew FRI 79651 (KEP [KEP237785]); Sungai Kuantan, 10 Jun 1934, Symington \& Kiah 28753 (SING [SING0230001]); Temerloh, 15 Dec 1920, Hamid CF 5489 (SING [SING0229982, SING0229983]). Penang: [Sulloh] Bahang, Sep 1885, Curtis 430 (SING [SING0229965]); Penang Botanic Gardens, 12 Jul 1918, Mhd 
Noor s.n. (SING [SING0229986]); ibidem, Jul 1937, Henderson 45 (SING [SING0229984]); Penang Hill, 4 Apr 1940, Nauen 37676 (SING [SING0229995]); ibidem, 26 Mar 1940, Nauen s.n. (SING [SING0229966]); Waterfall Valley, Mar 1901, Curtis 3609 (SING [SING0229981, SING0229997, SING0229998, SING0229999, SING0230000]); without precise locality, s.d., Unknown s.n. (SING [SING0229988]). Selangor: Sungai Buloh, 12 May 1918, Hamid CF 1760 (SING [SING0229991]); Sungai Buloh F.R., 27 Jun 1923, Abu CF 8879 (SING [SING0229990]). Terengganu: Kemaman, Bukit Kajang, 28 Nov 1935, Corner s.n. (SING [SING0229994]); Ulu Brang, Jul 1937, Moysey \& Kiah SFN 33883 (SING [SING0229968]).

SINGAPORE: Bukit Kallang Summit: 29 Oct 1996, Ali AI 293 (SING [SING0030084]); ibidem, 29 Oct 1996, Lai \& Ali LJ 96 (SING [SING0044592]). Bukit Timah Nature Reserve: 25 Apr 2006, Khoo KMS 13 (SING [SING0123507]); Jungle Fall Path, 2 Sep 2019, Choo et al. SING2019-839 (SING [SING0291102]); Fern Valley, 2 Sep 2019, Choo et al. SING2019840 (SING [SING0291103]). Central Catchment Nature Reserve: Mandai, 23 Nov 1992, Wong et al. 16 (SING [SING0144961]); Petaling Trail, opposite Tempinis Hut, 19 Apr 2010, Teo SING2010-740 (SING [SING0144870]). Singapore Zoo [Mandai Zoological Gardens]: Rainforest Trail, 19 Mar 1998, Ali \& Saiffudin AI 288 (SING [SING0011597]).

2. Sindora echinocalyx Prain, J. Asiat. Soc. Bengal, Pt. 2, Nat. Hist. 66(1): 204, 481 (1897); Symington, Bull. Misc. Inform. Kew 1938: 75, 77, f. B (1938); de Wit, Bull. Jard. Bot. Buitenzorg, ser. 3, 18: 34 (1949); Whitmore, Tree Fl. Malaya 1: 272 (1972); Larsen et al., Fl. Thailand 4(1): 99 (1984); Hou in Hou et al., Fl. Males., ser. 1, Spermat. 12(2): 698 (1996); Turner, Gard. Bull. Singapore 47: 310 (1997 ['1995']); Hou, Tree Fl. Sabah \& Sarawak 3: 170 (2000); Khoo et al., Gard. Bull. Singapore 70(1): 63 (2018). - TYPE: Peninsular Malaysia, Malacca, Griffith s.n. [Kew Distribution no. 1848] (lectotype L [L0019291], designated by de Wit, Bull. Jard. Bot. Buitenzorg, ser. 3, 18: 35 (1949); isolectotypes BM [BM000946683], C [C10012365], HBG [HBG519135], M [M0215207], P [P00835827], [P00835828], S [S13-12120]). (Fig. 3).

Sindora wallichii auct. non. Benth.: Bentham in Hooker, Icon. P1. 11: t. 1017 (1867); Ridley, Fl. Malay Penins. 1: 637 (1922).

Tree up to $40 \mathrm{~m}$, dbh up to $150 \mathrm{~cm}$, rarely recorded to be buttressed. Stipules slightly auriculate at the base, pubescent on both surfaces to sparsely puberulous only on the edges and at the midrib of the stipule, subpersistent, $0.8-1.8 \times 0.3-0.9 \mathrm{~cm}$. Leaves 3-jugate, rarely 2- or 4-jugate; rachis finely pubescent with short tomentose hairs to puberulous, becoming glabrous over time, lenticellate in parts, dark brown to black, 2.4-7 cm long, but in saplings considerably longer, 7.7-8.5 cm; petiole $(0.8-) 1.3-4$ $\mathrm{cm}$ long, in saplings up to $6 \mathrm{~cm}$ long; petiolules $2-3.5(-4) \mathrm{mm}$ long, pubescent with short fine hairs, densely pubescent in seedlings or saplings, sometimes twisted in dry specimens. Leaflets rough-textured on both upper and lower surfaces, lower surface usually rougher than the upper surface, elliptic to obovate, slightly asymmetrical at the base, midrib generally straight, $3.1-10.7 \times(1.6-) 2-5 \mathrm{~cm}$, in saplings up to 17 $\times 8.2 \mathrm{~cm}$, increasing in size up the rachis with the largest pair of leaflets at the tip, apex rounded to obtuse and slightly emarginate at the very tip, in saplings acute to 
acuminate; upper surface glabrous with the midrib sunken, occasionally minutely puberulous at the base, rarely in saplings finely pubescent with thin, straight hairs; lower surface usually puberulous with small, thin, strigose hairs in mature leaflets but occasionally glabrescent, midrib pubescent; thickened marginal vein densely pubescent to puberulous all over, or puberulous at the base and becoming glabrous towards the leaflet tip; reticulations clear and raised on both the upper and lower surfaces; one gland present on the tip of the midrib, covered by sparse hairs on the midrib on the lower surface of the leaflet, another 1-2 glands sometimes present close to the base of the leaflet appearing as thickened and hairless areas on the marginal vein. Inflorescence with long flowering rachises, 10-15 × 2-5 cm, side branches straight and not fractiflex; bracts persistent, foliaceous, broadly ovate or rounded, outer surface densely pubescent, inner surface pubescent to sparsely pubescent to glabrous, 3.5-6 $\times 3.5-9.5 \mathrm{~mm}$; bracteoles lanceolate to narrowly lanceolate, 3-4 × 1-2.5 mm long, pubescent on both surfaces, subpersistent, seen even on mature buds; pedicels 4-6 mm long; receptacle short, 1-1.5 mm; buds elliptic to obovoid, armed with long spines up to $2 \mathrm{~mm}$ scattered across the entire bud surface, 6-8 $\times 4-5.5 \mathrm{~mm}$ when mature just before anthesis. Sepals 6-8.5 × 1.5-3.9 mm, outer surface armed all over with long, soft spines that are brittle when dry, spines up to $2 \mathrm{~mm}$ long. Petal boat-shaped with the edges curved upwards, 7.5-9.5 × 1.75-3 mm, outer surface glabrous except at the sides of the base, the margins and the keel at the back of the petal, which are densely tomentose, margin along the top tomentose. Stamens 9-10, united basal portion of the stamens 1.9-2.4 mm long, filaments 4.7-11.5 mm long; the two largest anthers c. $2.5 \times 1.2 \mathrm{~mm}$, the other anthers c. $1.3 \times 0.8 \mathrm{~mm}$. Ovary subrhomboid, densely villous, surface armed with small, blunt, black spines that are longer than the hairs on the ovary, 3.5-7 × 3-5 mm, stipe c. $2.2 \mathrm{~mm}$ long; style pubescent at the base but becoming glabrous up the length of the style, c. $9 \mathrm{~mm}$. Pods elliptic, usually broader than long, or round to ovate, armed with upright, regularly spaced spikes that range from stout to slender, often with small amounts of dried resin at the tips of the spines, surface beneath the spines smooth, pubescence persistent in the pod edges and spines, dark brown to black in colour, 3.6-5.5(-7.7) $\times 3.7-7.2 \mathrm{~cm}$, stipe 4-11 mm, beak 4-8 mm. Seeds 1-2, aril trapezoid and obliquely-placed, c. $1.5 \times 1.3 \times 0.6 \mathrm{~cm}$, seed c. $2.1 \times 1.1$ $\times 0.6 \mathrm{~cm}$, surface smooth and uniformly black.

Distribution. Peninsular Thailand, Riau Archipelago, common in the Malay Peninsula. In Peninsular Malaysia the species is widespread and has been recorded from Kedah, Perak, Selangor, Negri Sembilan, Malacca, Kelantan, Terengganu, Pahang and Johor, as well as Singapore. The sole recorded collection of Sindora echinocalyx from Sabah, Borneo (Maidin 6258, SING [SING0230177] and L [L1995506]) has been re-determined as $S$. coriacea. As such, the range of Sindora echinocalyx no longer includes Borneo.

Ecology. Sindora echinocalyx is known from evergreen forests on hillsides and ridges up to $800 \mathrm{~m}$, coastal hill forests, seashores, offshore islands and coastal heath forests (Saw, 2009). 
Etymology. Latin, echinus $=$ hedgehog or sea-urchin, calyx $=$ calyx; referring to the spiny outgrowths on the calyx of the flowers, which resemble the spines of the hedgehog or sea-urchin.

Vernacular names. Sepetir, Sepetir daun nipis (Malay).

Uses. The wood is used mainly for indoor construction.

Provisional IUCN conservation assessment. Sindora echinocalyx is provisionally assessed here to be of Least Concern (LC) globally, as the species is widespread across its range in Thailand, Peninsular Malaysia and Singapore. In Peninsular Malaysia it is also known to be common and widely distributed and is also provisionally assessed here to be of Least Concern (LC). In Singapore it is assessed here to be Critically Endangered (CR/D), based on the criteria in Davison et al. (2008), as there are likely to be fewer than 250 mature trees and these are found only in primary forests or as remnant individuals in mature secondary forests which are fragmented habitats in Singapore.

Specimens examined. PENINSULAR MALAYSIA: Johor: Mersing, Pulau Tinggi, 16 Apr 1967, FSP Ng FRI 5044 (SING [SING0230006]); Pulau Merambong, 29 Sep 1935, Corner s.n. (SING [SING0018542]); Pulau Tinggi, 21 Jun 1996, Unknown PT 96-293 (SING [SING0230090]). Malacca: Bukit Sedanan, 16 Oct 1933, Abdul Hadi 18283 (SING [SING0230009]); Bukit Senggeh F.R., 16 Jun 1966, Ng FRI 1198 (SING [SING0230146]); ibidem, 16 Jun 1966, Ng FRI 1201 (SING [SING0230158]); wthout precise locality, 13 Mar 1885, Alvins 1189 (SING [SING0230092]). Negeri Sembilan: Port Dickson, Sg. Menyala F.R., 17 Jun 1947, Wyatt-Smith 64849 (KEP [KEP196939]); Tanjung Agas State Land, 1 Apr 1919, Usop CF 557 (SING [SING0230098]); Gunung Tampin, 22 Nov 1922, Holttum 9530 (SING [SING0230088]). Pahang: Jerantut, Tekam F.R., 10 Jul 1979, Kamarudin FRI 28611 (KEP [KEP129879]); Temerloh, Kampung Belingo, 23 Sep 1927, Pawanchee FMS 13775 (SING [SING0230095, SING0230118]). Perak: Bintang Hijau F.R., 14 Jul 1966, Chelliah KEP 98625 (SING [SING0230160]); Dindings, Lumut, Jul 1890, Ridley s.n. (SING [SING0230089]); ibidem, Jul 1900, Curtis s.n. (SING [SING0230094]); ibidem, 8 Sep 1908, Ridley s.n. (SING [SING0229970]); ibidem, 29 Aug 1931, Symington 27773 (SING [SING0230008]); Dindings, Manjung [Manajung], Sep 1904, Fox s.n. (SING [SING0230097]); Pangkor Island, North Coast, 17 Feb 1967, Whitmore FRI 3004 (SING [SING0230157]); Telok Muroh F.R., Compt. 7, 14 Jul 1953, Wyatt-Smith 76735 (SING [SING0230093]). Terengganu: Gunung Tebu F.R., Compt. 90, 31 Jan 1970, Kochummen FRI 2504 (SING [SING0230010]).

SINGAPORE: Chestnut Avenue: 20 May 2008, Gwee et al. SING2008-182 (SING [SING0113853]). Central Catchment Nature Reserve: MacRitchie F.R., Sime Track, 17 Jan 2014, Leong et al. MR 2014-107 (SING [SING0212464, SING0212465]); ibidem, 17 Jan 2014, Leong et al. MR 2014-108 (SING [SING0212466]); Mandai, off Plot 39 Peninsula, 6 Jan 2009, Gwee et al. SING2009-06 (SING [SING0123510]); Mandai, 2 Feb 2010, Gwee SING2010-297 (SING [SING0144606]); Nee Soon Swamp Forest, 15 Jul 2003, Samsuri et al. NES 61 (SING [SING0045770]); Upper Peirce 4, 19 Jan 2010, Gwee SING2010-105 (SING [SING0144354]).

Changi: 1893, Bakar s.n. (SING [SING0044593]). 
3. Sindora siamensis Teijsm. ex Miq., Ann. Mus. Bot. Lugduno-Batavi 3: 86 (1867); Ridley, Fl. Malay Penins. 1: 638 (1922); de Wit, Bull. Jard. Bot. Buitenzorg, ser. 3, 18: 62, f. 13 (1949); Whitmore, Tree Fl. Malaya 1: 272 (1972); Larsen \& Larsen, Fl. Cambodge, Laos \& Vietnam 18: 125, pl. 21/1-4 (1980); Larsen et al., Fl. Thailand 4(1): 100, f.25/1-5 (1984); Hou in Hou et al., Fl. Males., ser. 1, Spermat. 12(2): 703 (1996); Turner, Gard. Bull. Singapore 47: 310 (1997 ['1995']). - Sindora wallichii Benth. var. siamensis (Teijsm. ex Miq.) Baker in Hooker, Fl. Brit. India. 2: 268 (1878). - TYPE: Siam [Thailand], Radboerie [probably Ratchaburi], s.d., Teijsmann 6050 (lectotype BO [BO1254784], first step designated by Hou in Hou et al., Fl. Males., ser. 1, Spermat. 12(2): 703 (1996), second step designated here; isolectotypes BO [BO1254785], [BO1254786], K [K000780066], U [U0003318], [U0003319]). (Fig. $1 \mathrm{~F}, 2$ \& 3).

Distribution. Cambodia, Laos and Thailand, rare in northern Peninsular Malaysia.

\section{var. siamensis}

Tree small to medium sized, up to $20 \mathrm{~m}$ tall, bark on trunk grey-brown, thick, corky and peeling in rectangular pieces, bark on younger branches smooth and uniformly brown. Stipules pubescent on both surfaces, late caducous, c. $0.9 \times 0.5 \mathrm{~cm}$. Leaves 3-4-jugate; rachis finely pubescent to tomentose, glabrescent, $5-7.7 \mathrm{~cm}$ long; petiole $1.4-3.5 \mathrm{~cm}$ long; petiolules 4-6 $\mathrm{mm}$ long, densely pubescent to pubescent to tomentose. Leaflets sometimes slightly rough on both upper and lower surfaces, broadly elliptic, mostly symmetrical except at the base which is unequal, 4.2-10.9 $\times 4-6.5 \mathrm{~cm}$, increasing in size up the rachis with the largest pair of leaflets at the tip, apex emarginate; upper surface glabrous or puberulous with short, fine, golden hairs, midrib flat or slightly raised, glabrous with a few sparse hairs or puberulous with small tomentose hairs and glabrescent over time; lower surface densely puberulous with short, fine, golden hairs, or glabrous except for the midrib and leaflet base which is slightly puberulous, midrib densely to sparsely puberulous; thickened marginal vein puberulous at the base and becoming glabrous towards the leaflet tip; reticulations very slightly raised on both the upper and lower surfaces; one gland present 1-3 mm away from the tip of the midrib on the lower surface of the leaflet, another gland sometimes present close to the base of one side the leaflet. Inflorescence with long and stout flowering rachises, 20.5-31 $\times 3-6 \mathrm{~cm}$, side branches clearly fractiflex; bracts persistent, foliaceous, broadly ovate, pubescent on both surfaces, c. $5 \times 4.5 \mathrm{~mm}$; bracteoles lanceolate to ovate, c. $4.5 \times 3.5$ $\mathrm{mm}$ long, pubescent on both surfaces, persistent; pedicels $4.5-5 \mathrm{~mm}$ long; receptacle short, $1-1.5 \mathrm{~mm}$; buds elliptic, surface warty with a few short spines up to $0.7 \mathrm{~mm}$ long at the top of the bud, 5-6.5 $\times 3.5-5.5 \mathrm{~mm}$ when mature just before anthesis. Sepals $6.5-9 \times 1.7-5.9 \mathrm{~mm}$, outer surface yellow-brown tinged with yellow-green, warty all over with few short spines towards the tip, inner surface pale brown and pubescent. Petal elliptic to narrowly ovate with an acute tip, 4.4-6.4 × 2.4-3.1 mm, outer surface almost entirely brown tomentose, except for the top quarter where the tip is sparsely pubescent and the green surface is visible, margin along the top tomentose. 


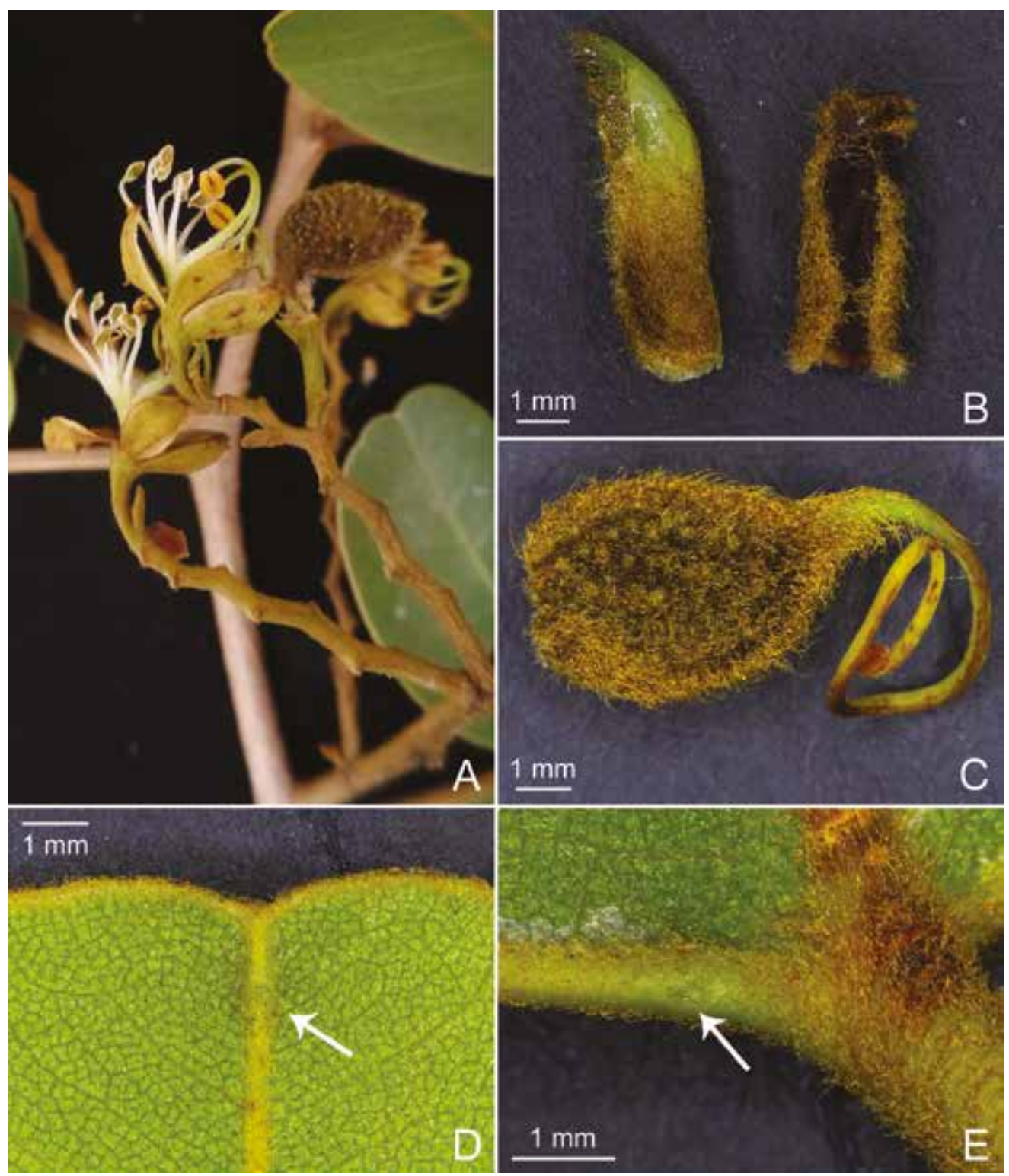

Fig. 2. Sindora siamensis Teijsm. ex Miq. A. Flowers on a fractiflex flowering rachis. B. Petal; left: side view of a fresh petal, right: ventral view of a dried petal. C. Ovary of a dissected flower, showing the short, blunt spines on the surface. D. Gland on the midrib located approximately $1 \mathrm{~mm}$ away from the tip, as seen from the lower surface E. Gland on the base of leaflet margin near the petiolule, as seen from the lower surface. All from a cultivated tree at Singapore Botanic Gardens. (Photos: L.M. Choo).

Stamens 10, united basal portion of the stamens 1.1-1.3 $\mathrm{mm}$ long, two longest filaments pale green when fresh, other filaments white when fresh, 3.6-10 mm long; the two largest anthers c. $3.2 \times 1.8 \mathrm{~mm}$, orange in colour when fresh, the other anthers 
$1.5-1.8 \times 0.7-1.3 \mathrm{~mm}$ and pale orange in colour. Ovary semicircular to circular, light brown, densely covered with villous hairs on the entire surface of the ovary, surface of ovary grooved with lengthwise strips of shorter hairs where the short, blunt spines sticking out from underneath the hairs are more visible, $4.1-5 \times 2.9-3.6 \mathrm{~mm}$, sessile; style green, pubescent only at the base and glabrous elsewhere on the style, 11.3-13 $\mathrm{mm}$; stigma with small, clear yellow-brown papillae dotted on the entire surface. Pods ovate, armed with short, stout, irregularly spaced spikes with an inflated base set on a warty surface, dark brown to black in colour, 4.5-6 $\times 4.3-5 \mathrm{~cm}$, stipe 3-6 mm, beak 4-6 mm. Seeds 1-2(-7), aril dark brown when dry, hard and slightly rough, placed at the top of the seed like a cap, c. $1.2 \times 1.7 \times 0.6 \mathrm{~cm}$, seed c. $1.6 \times 1.5 \times 0.9 \mathrm{~cm}$, surface smooth and black, not shiny, resembling a flattened, circular disk.

Distribution. Cambodia, Laos, Thailand and Vietnam, rare in northern Peninsular Malaysia. Only one collection of Sindora siamensis var. siamensis has been made by Ridley in Kelantan, Peninsular Malaysia (Ridley s.n., 17 Feb 1917, K).

Ecology. The species is dominant in the lowland and dry dipterocarp forests of Thailand and northwards up to an altitude of $500 \mathrm{~m}$. It is also frequent in the beach forests of Thailand, Cambodia and Vietnam. It is rarer in the southernmost part of Thailand, which represents the southern limit of its range.

Etymology. Latin, siamensis = of Siam, the old name for Thailand; referring to the type locality of the species which is in Thailand.

Vernacular names. Sepetir, Sepetir mempelas (Malay); Makha tae (Thai).

Uses. The wood is used to make planks, poles, furniture, and also as firewood. In Thailand, the bark is used for wall partitions, the wood-oil for caulking boats and the aril of the seed is sometimes chewed as a substitute for betel.

Provisional IUCN conservation assessment. Sindora siamensis is provisionally assessed here to be of Least Concern (LC) globally. In Peninsular Malaysia however, the species has only been collected once and has not been recorded since 1917, hence it is assessed here as presumed Nationally Extinct in Peninsular Malaysia.

Additional specimens examined. PENINSULAR MALAYSIA: Kelantan: Gunung Kota Bahru [but probably intended to mean a mountain near Kota Bahru], 17 Feb 1917, Ridley s.n. (K [K001129690]).

SINGAPORE: Cultivated in Singapore Botanic Gardens: 20 Aug 1890, Ridley 2079 (SING [SING0036456]); ibidem, 1891, Ridley 2078 (SING [SING0261537, SING0261538]); ibidem, Aug 1893, Ridley 9807 (K [K001129691]); Economic Gardens, 13 Jun 1924, Mhd Nur 152 or 1590 (SING [SING0261541]); ibidem, 24 Jul 1917, Mhd Nur 1303 (KEP [KEP220015]).

THAILAND: Central Thailand: Lop Buri, Koh Lak, 2 Apr 1919, Hamid FMS 3800 (KEP [KEP196793]); Lop Buri, Chai Badan, Lop Buri to Tha Luang road no. 205, km 217 before Muang Khom intersection, 20 Apr 2004, Pooma 3810 (SING [SING0076887]). South-Western Thailand: Prachuap Khiri Khan, Kui Buri NP, 11 Jun 2006, Williams 1617 (KEP [KEP1617]). 


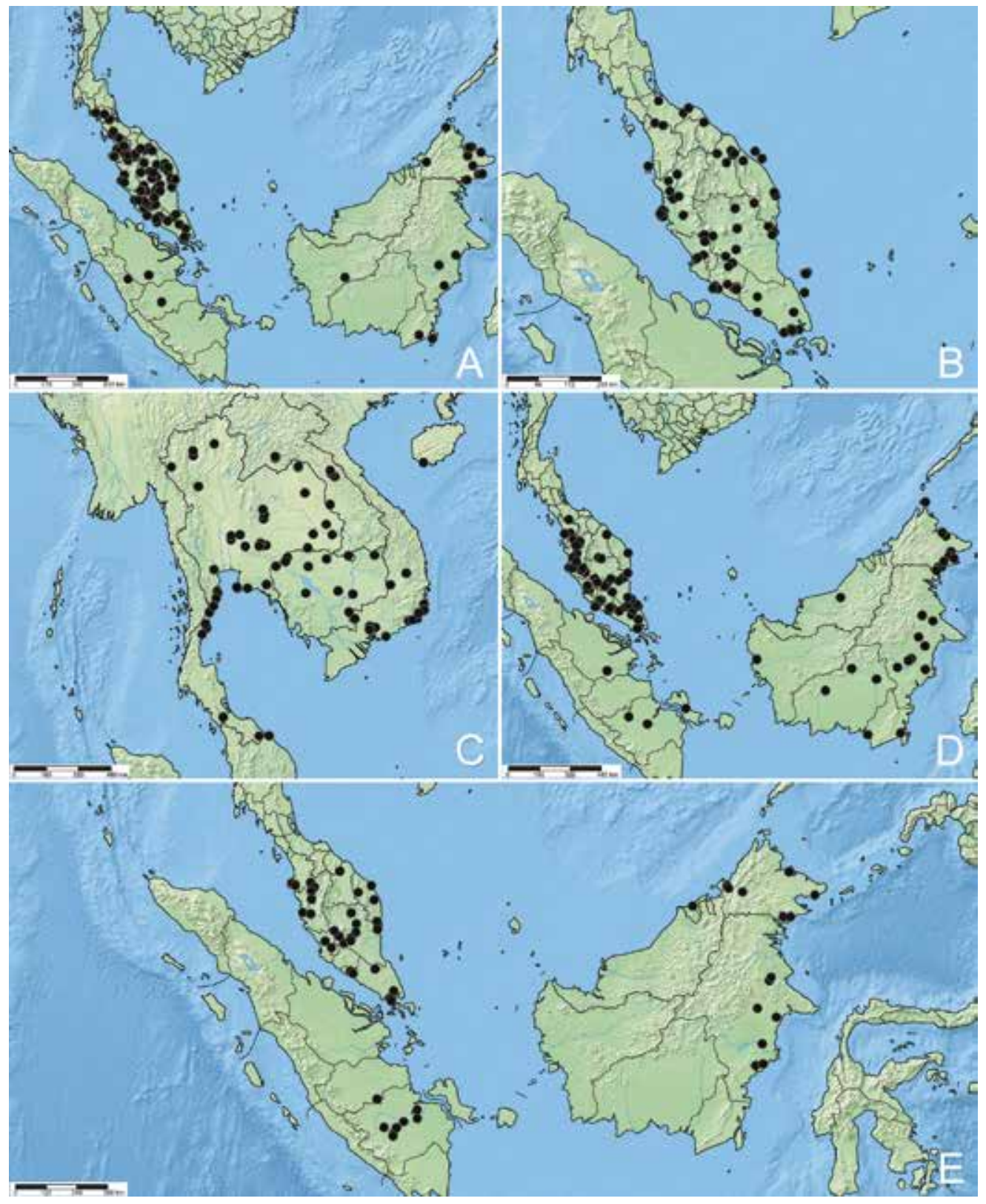

Fig. 3. Maps of all recorded localities of Sindora species. A. Sindora coriacea. B. Sindora echinocalyx. C. Sindora siamensis. D. Sindora velutina. E. Sindora wallichii.

Notes. A range of floral and fruit characters are taken from cultivated specimens and specimens from Thailand as there are insufficient flowering and fruiting specimens from Peninsular Malaysia.

Sindora siamensis var. siamensis differs from S. siamensis var. maritima in the armed and spiky pods while the pods of S. siamensis var. maritima are unarmed and 
spineless or with only a few small spines or warts. Sindora siamensis var. maritima is also less common and has a more restricted distribution in Thailand and Cambodia and is not found in Peninsular Malaysia.

4. Sindora velutina Baker in Hooker, Fl. Brit. India 2(5): 269 (1878); Prain, J. Asiat. Soc. Bengal, Pt. 2, Nat. Hist. 66(1): 205 (1897); Ridley, Fl. Malay Penins. 1: 638 (1922); de Wit, Bull. Jard. Bot. Buitenzorg, ser. 3, 18: 72, f. 14 (1949); Whitmore, Tree Fl. Malaya 1: 273 (1972); Hou in Hou et al., Fl. Males., ser. 1, Spermat. 12(2): 707 (1996); Turner, Gard. Bull. Singapore 47: 310 (1997 ['1995']); Hou, Tree Fl. Sabah \& Sarawak 3: 172 (2000). - TYPE: Peninsular Malaysia, Malacca, 1867-1868, Maingay 2487 [Kew Distribution no. 607] (lectotype K [K001129692], first step designated by de Wit, Bull. Jard. Bot. Buitenzorg, ser. 3, 18: 74 (1949), second step designated here; isolectotype K [K001129693]). (Fig. 1D-E \& 3).

Sindora parvifoliola Symington, Bull. Misc. Inform. Kew 1938: 77 (1938). - TYPE: Peninsular Malaysia, Pahang, Kuala Rompin, 25 Sep 1921, Bidin C.F. 4192 (holotype KEP [168475]).

Tree up to $40 \mathrm{~m}$, dbh up to $60 \mathrm{~cm}$, rarely with short buttresses to $30 \mathrm{~cm}$ high, 7.5 $\mathrm{cm}$ thick, bark surface with distant mid-sized lenticels, exudate watery and slow to appear. Stipules not seen, caducous. Leaves 4-6-jugate; rachis in young leaves densely tomentose with golden brown hairs, completely obscuring the surface of the rachis, but in mature leaves glabrescent, usually minutely puberulous except for tomentose patches where the petiolules join the rachis, surface slightly warty, brown to reddish brown to dark brown, (5-)7-15.3 cm long; petiole 1.1-4 cm long; petiolules (1.5-)2-4 $\mathrm{mm}$ long, densely tomentose with long hairs, rarely sparsely pubescent in very worn specimens. Leaflets smooth above and soft-velvety to rough below, elliptic to lanceolate, generally symmetrical with a straight midrib except for a slightly asymmetrical base, $3-11.6 \times 1.3-4.6 \mathrm{~cm}$, basal pair of leaflets usually the smallest and other pairs of leaflets are generally of similar sizes, apex acuminate to acute to attenuate; upper surface glabrous with the midrib sunken, midrib generally glabrous but occasionally with a few long, thin, straight hairs scattered near the base of the midrib; lower surface densely covered with upright villous or tomentose hairs, midrib also densely hairy, entire lower surface distinctly velvety or hairy to touch, seemingly glabrescent in old and worn specimens or fallen leaflets; thickened marginal vein with variable amounts of pubescence, tomentose to puberulous to glabrous, sometimes more densely hairy at the base but becoming glabrous towards the leaflet tip; reticulations slightly raised on both the upper and lower surfaces; one gland present on the tip of the midrib on the lower surface of the leaflet, but sometimes obscured by hairs, another 1-2 glands present close to the base of one or both sides of the leaflet, visible only from the lower surface, appearing as a hairless clearing on the marginal vein, sometimes obscured by hairs. Inflorescence with relatively short flowering rachises, sometimes with more than one rachis emerging from a single point, $7-18 \times 2-4 \mathrm{~cm}$, side branches clearly 
fractiflex, reddish-brown pubescence on inflorescence so dense that the surface of the flowering rachises is completely obscured; bracts not seen, caducous; bracteoles triangular to lanceolate, $2-3.5 \times 0.8-3 \mathrm{~mm}$ long, densely pubescent on the outer surface as in the rest of the inflorescence, inner surface glabrous and dark brown to black in dry specimens, caducous; pedicels $3.5-5.5 \mathrm{~mm}$ long; receptacle short, 1-1.5 mm; buds elliptic, surface unarmed, 6-8 $\times 3.5-4.5 \mathrm{~mm}$ when mature just before anthesis. Sepals 6-10 × 1.7-4.5 mm, outer surface unarmed, sometimes covered with fine, straight, upright hairs instead of tomentose hairs. Petal boat-shaped with the edges curved upwards, $6.1-7.5 \times 1.7-2.3 \mathrm{~mm}$, outer surface densely pubescent but becoming sparse towards the tips such that the black surface is visible, keel on outer surface usually visible except at the base, margin along the top tomentose. Stamens 10, united basal portion of the stamens 2.5-3.3 mm long, filaments 5.3-14.4 mm long; the two largest anthers c. $3.3 \times 1 \mathrm{~mm}$, the other anthers c. $1.4 \times 0.9 \mathrm{~mm}$. Ovary semicircular to trapezoid, densely covered with villous hairs on the entire surface of the ovary, surface not visibly armed, $4.1-7 \times 2.6-3.3 \mathrm{~mm}$, stipe c. $2 \mathrm{~mm}$ long; style pubescent at the base but becoming glabrous up the length of the style, 8.5-9 mm. Pods elliptic to ovate to round, armed with short, regularly spaced fine or stout spines with an inflated base, walls of spines thickened with a very small pore, sometimes with hardened beads of dried resin at the tips of the spines, surface beneath the spines rough and finely warty, pubescence persistent in the pod edges and spines, orange brown to dark brown to black in colour, 5.5-15.8 $\times 5.3-10.1 \mathrm{~cm}$, stipe 5-10 mm, beak c. $4 \mathrm{~mm}$. Seeds $1-2$, aril yellow-orange when fresh and yellow-brown when dry, with a cinnamon-like scent, rectangular and capped centrally on seed, 1.5-2.1 $\times 1.4-1.6 \times 0.5-0.9 \mathrm{~cm}$, seed elliptic, $1.4-1.9 \times 1.1-1.5 \times 0.5-0.8 \mathrm{~cm}$, surface smooth and entirely black.

Distribution. Peninsular Malaysia, Singapore, Sumatra and Borneo. In Peninsular Malaysia the species has been recorded from Kedah, Perak, Selangor, Negeri Semblian, Malacca, Kelantan, Terengganu, Pahang and Johor, as well as Singapore.

Ecology. The species is often found scattered in dryland and hillside forest, and rarely found growing along river banks and swamps, usually at a low altitude of less than 160 $\mathrm{m}$, but it has been recorded from an altitude of $670 \mathrm{~m}$ from Gunung Bubu in Perak. The species is closely associated with primary rainforests and has been noted by de Wit (1949) to disappear when the primary rainforest is removed.

Etymology. Latin, velutinus = velvety, referring to the dense woolly or velvety pubescence on young branchlets, inflorescences and the undersides of leaflets.

Vernacular names. Sepetir, Sepetir beledu, Sepetir beledu besar, Sepetir beledu kecil (Malay).

Uses. The timber is used in construction and for making household utensils. The woodoil is used traditionally as a medicine. 
Provisional IUCN conservation assessment. Least Concern (LC) globally (Barstow, 2019b). Within Peninsular Malaysia the species has a scattered distribution but is provisionally assessed here to be of Least Concern (LC). In Singapore the species is provisionally assessed to be Critically Endangered (CR), based on the criteria in Davison et al. (2008), as there are likely to be fewer than 50 mature trees.

Specimens examined. PENINSULAR MALAYSIA: Johor: Kluang F.R., Compt. 77, 15 Nov 1966, Kochummen FRI 2194 (SING [SING0230101]); Maokil F.R., 5 miles south of Labis, 29 Aug 1950, Sinclair SFN 38998 (SING [SING0230106]); Ulu Kahang, May 1923, Holttum 10781 (SING [SING0230105]). Kedah: Gunung Jerai, 12 Jun 1966, Whitmore FRI 0393 (SING [SING0230100]); Kuala Muda, Gunung Jerai, 8 May 1954, Unknown FMS 20795 (KEP [KEP196901]). Malacca: Ayer Panas, 1893, Ridley 5815 (SING [SING0230107]). Pahang: Jengka F.R., 25 Feb 1966, Whitmore FRI 0066 (SING [SING0230099], KEP [KEP196998]); Kuantan, 14 Jul 1921, Lambak CF 3554 (SING [SING0230110, SING0230111]); Kuantan, 6 Jun 1921, Sahor CF 4187 (SING [SING0230108, SING0230109]); Kuantan, Baloh F.R., Compt. 5, 23 Jul 1966, Ramli 97910 (SING [SING0230102]); Tasoh Bera, 14 Oct 1930, Henderson s.n. (SING [SING0230116]); Temerloh, 25 Aug 1919, Hamid CF 4793-A (SING [SING0230117]); Temerloh, 14 Dec 1920, Hamid CF 5488 (SING [SING0230103, SING0230104]). Perak: Gunung Bubu, 22 Feb 1970, Suppiah FRI 11925 (SING [SING0230096], KEP [KEP196847]). SINGAPORE: Nee Soon Rifle Range: 6 Feb 1954, Sinclair SFN 40186 (SING [SING0044594, SING0044595]). Bukit Timah Nature Reserve: Seraya Loop, 6 Aug 2019, Choo et al. SING2019-706 (SING [SING0291099]); Jungle Fall Stream, 25 Sep 2019, Choo et al. SING2019-944 (SING [SING0291105]), ibidem, 9 Oct 2019, Choo et al. SING2019-993 (SING [SING0291106]).

Notes. Sindora velutina was only recorded recently in Singapore by Wong et al. (2013), but without any specimen data and as presumed nationally extinct. It is likely that this was based on the 1954 Sinclair collection. Here we confirm the presence of the species in Singapore, expand the distribution of the species to Bukit Timah Nature Reserve, and note that it is has been rediscovered based on our recent collections and is no longer to be presumed nationally extinct.

5. Sindora wallichii Benth. in Hooker, Icon. Pl. 11: t. 1018 (excl. t. 1017) (1867); Baker in Hooker, Fl. Brit. India 2(5): 268 (1878), p.p.; Prain, J. Asiat. Soc. Bengal, Pt. 2, Nat. Hist. 66(1): 203, 481 (1897) (as 'wallichiana'); Ridley, Fl. Singapore 75 (1900) (as 'wallichiana'); Ridley, Fl. Malay Penins. 1: 637 (1922); Symington, Bull. Misc. Inform. Kew 1938: 75, 77, f. A (1938); de Wit, Bull. Jard. Bot. Buitenzorg, ser. 3, 18 : 76 (1949); Whitmore, Tree Fl. Malaya 1: 273 (1972); Keng, Concise Fl. Singapore, vol. 1, Gymn. Dicot 39 (1990); Turner, Gard. Bull. Singapore 45: 122 (1993); Hou in Hou et al., Fl. Males., ser. 1, Spermat. 12(2): 708 (1996); Turner, Gard. Bull. Singapore 47: 310 (1997 ['1995']); Hou, Tree Fl. Sabah \& Sarawak 3: 173 (2000); Chong et al., Checkl. Vasc. P1. Fl. Singapore 80, 136, 211 (2009). - TYPE: Singapore, 1822, Wallich s.n. [EIC 5805] (lectotype K [K000780069], first step designated by Hou in Hou et al., Fl. Males., ser. 1, Spermat. 12(2): 708 (1996), second step designated here; isolectotypes BM [BM000946682], K [K000780070]). (Fig. 1A-B \& 3). 
Sindora wallichii var. intermedia Baker in Hooker, Fl. Brit. India 2(5): 268 (1878), p.p. - Sindora intermedia (Baker) Prain, J. Asiat. Soc. Bengal, Pt. 2, Nat. Hist. 66(1): 204, 482 (1897); Ridley, Fl. Singapore 75 (1900); Ridley, Fl. Malay Penins. 1: 638 (1922). - TYPE: Peninsular Malaysia, 28 April 1868, Maingay 3142 [Kew Distribution 562] (lectotype K [K001129694], designated by Hou in Hou et al., Fl. Males., ser. 1, Spermat. 12(2): 708 (1996)).

Tree up to $40 \mathrm{~m}$, dbh up to $80 \mathrm{~cm}$, crown rounded and dense, usually unbuttressed, rarely with steep buttresses up to $1.2 \mathrm{~m}$. Stipules slightly auriculate at the base, pubescent on both surfaces, late caducous, $1.1-1.4 \times 0.5-0.8 \mathrm{~cm}$. Leaves $3-4$-jugate, rarely 2 -jugate; rachis pubescent to densely pubescent to tomentose or minutely puberulous with short adpressed hairs, surface reddish brown to dark brown, 1.5-5.5 cm long; petiole 0.9$1.9 \mathrm{~cm}$ long; petiolules $2-3.5 \mathrm{~mm}$ long, pubescent to sparsely pubescent, sometimes twisted in dry specimens. Leaflets smooth above but slightly rough below, elliptic to obovate, asymmetrical at the base, midrib generally curved, especially so in the leaflets towards the rachis tip, $3.1-8.6 \times 1.8-3.4 \mathrm{~cm}$, increasing in size up the rachis with the largest pair of leaflets at the tip, apex rounded to obtuse with a slight emarginate tip, to acute or very rarely acuminate; upper surface smooth, glabrous and very glossy with the midrib sunken, in young leaves may be pubescent with fine adpressed hairs; lower surface puberulous to sparsely puberulous with small, thin, adpressed hairs, becoming glabrous over time, midrib puberulous to densely pubescent in saplings; thickened marginal vein densely pubescent to puberulous to sparsely puberulous to glabrous, usually denser at the base of the leaflet and glabrescent towards the leaflet tip; reticulations faint and not raised on the upper surface, only slightly raised on the lower surface; one gland present on the tip of the midrib on the lower surface of the leaflet, another gland present close to the base of the leaflet appearing as thickened and hairless areas on the marginal vein, rarely two glands present at the base on each side of the marginal vein. Inflorescence with long flowering rachises, $8.5-16.5 \times 2-3 \mathrm{~cm}$, side branches fractiflex; bracts persistent or tardily falling, broadly triangular, base clasping, pubescent on both surfaces, 4-8.5 $\times 3.5-7 \mathrm{~mm}$; bracteoles ovate but tapering from a broad base to a small stalk, 2.5-4 mm long, pubescent on both surfaces, caducous; pedicels 4.5-5 mm long; receptacle short, 1-2 mm; buds obovoid, armed with short spines or warts less than $1 \mathrm{~mm}$ only on the upper half or sometimes only at the very tip of the bud, 9-10 $\times 4.5-6.5 \mathrm{~mm}$ when mature just before anthesis; inflorescence reportedly bronze and bright red, with an unpleasant and weakly musty scent when fresh. Sepals 4, with bronze-coloured hairs outside and inside with golden silky hairs, $5.9-10.5 \times 2.1-6 \mathrm{~mm}$, outer surface armed only on the upper half or on the very tip of the bud, with warts and short spines 1-2 mm long that are brittle when dry. Petal boat-shaped with the edges curved upwards, bright red and white in fresh specimens but black when dry, 5-9.1 × 1.7-2.1 mm, outer surface densely tomentose all over, margins tomentose. Stamens 9-10, united basal portion of the stamens 2.3-4 mm long, filaments dark purple but slightly lighter towards the base in fresh specimens, 4.2-15 mm long; the two largest anthers $2.9-3.7 \times 0.8-1.1 \mathrm{~mm}$, the other anthers c. $1.5 \times 0.5 \mathrm{~mm}$. Ovary semicircular to elliptic, densely covered with villous hairs on the 
entire surface of the ovary, but with grooved areas of shorter hairs lengthwise across the surface, surface slightly warty with small, slightly raised black spines that are only scarcely visible above the dense pubescence, $3.8-5.5 \times 2.5-2.8 \mathrm{~mm}$, stipe $1.2-3 \mathrm{~mm}$ long; style sparsely villous at the base but possibly becoming glabrous apically, 1.3$1.8 \mathrm{~cm}$ long. Pods round to elliptic to oblong, armed with small, short, slender spines in young fruits but later becoming stout with wide, inflated bases, spines regularly spaced in young fruit but later irregularly spaced as the pod matures, often with small amounts of dried resin at the tips of the spines, surface beneath the spines smooth, dark brown to black in colour, 3.2-9.5(-15.5) $\times 2.7-7.7 \mathrm{~cm}$, stipe $6-14 \mathrm{~mm}$, beak 4-9 $\mathrm{mm}$. Seeds 1-3, aril chestnut brown blending into yellow-ochre when fresh and chestnut brown when dry, with an oily or slightly rancid scent, ovoid or trapezoid and obliquely capped on seed, $1.7-1.9 \times 1.2-1.4 \times 0.6 \mathrm{~cm}$, seed elliptic, $1.5-1.8 \times 1.4-1.7 \times 0.7-0.9$ $\mathrm{cm}$, surface smooth and dark maroon to almost black in colour.

Distribution. Peninsular Malaysia, Singapore, Sumatra and Borneo. In Peninsular Malaysia the species has been recorded from Penang, Perak, Malacca, Kelantan, Terengganu, Pahang and Johor, as well as Singapore.

Ecology. The species is locally common in lowland hill dipterocarp forests or primary forests on sandy or clayey soils, and sometimes in freshwater swamp forests or near mangrove swamps at an altitude of $100 \mathrm{~m}$ or less and is rarely recorded at altitudes of up to $300 \mathrm{~m}$ (Saw, 2010).

Etymology. Latin, wallichii = of Wallich; a reference to Nathaniel Wallich (17861854), the Superintendent of the Calcutta Botanic Gardens in India.

Vernacular names. Sepetir, Sepetir daun tebal (Malay); Meketil (Malay but only used in the northern states of Kedah and Kelantan).

Uses. The timber is used for construction, while the pods are used as traditional medicine after childbirth.

Provisional IUCN conservation assessment. Sindora wallichii has a widespread distribution and is provisionally assessed here to be of Least Concern (LC) globally. It is also provisionally assessed as Least Concern (LC) in Peninsular Malaysia as the species is frequent in lowland and hill dipterocarp forests, which are common habitats in Peninsular Malaysia. In Singapore however there are fewer than 50 known mature trees in the wild and the species is provisionally assessed as Critically Endangered (CR) based on the criteria in Davison et al. (2008).

Specimens examined. PENINSULAR MALAYSIA: Johor: Sungai Tiram, 25 Feb 1955, Sinclair SFN 40530 (SING [SING0230139]). Malacca: Compt. 3A, 30 Mar 1933, Unknown CF 25213 (SING [SING0230140]). Pahang: Jerantut, Sg. Tekam F.R., 13 Apr 1983, Ang FRI 27666 (KEP [KEP220011]); Kuantan, path leading to Baloh F.R., 27 Jul 1966, Rahim KEP 97922 
(SING [SING0230113]); Temerloh, 25 Aug 1919, Hamid CF 4793 (SING [SING0230141]); Temerloh, 25 Aug 1919, Hamid CF 4793-B (SING [SING0230117]). Penang: Butterworth [Province Wellesley], 1 Aug 1905, Forest Guard s.n. (SING [SING0230142]). Perak: Changkat Keruing, Gunung Tunggal, Jul 1888, Curtis 1630 (SING [SING0230138, SING0230112]); Hulu Perak, Papulut FR, 7 Jul 1966, Whitmore FRI 537 (KEP [KEP196913]). Terengganu: Kuala Terengganu, Bukit Tok Beng, 16 May 1925, Holttum 15345 (SING [SING0230137]); Ulu Sungei Terengganu, near Jeram Galong, 31 May 1968, Cockburn FRI 8379 (SING [SING0230151]).

SINGAPORE: Bukit Timah Nature Reserve: Seraya Valley, 12 Oct 2006, Khoo \& Nik KMS 16 (SING [SING0123508]); ibidem, 30 Jan 2009, Khoo KMS 65 (SING [SING0123509]); Fern Valley, 22 Jul 2019, Choo et al. SING2019-655 (SING [SING0291097]); ibidem, 25 Sep 2019, Choo et al. SING2019-943 (SING [SING0291104]). Pulau Blakang Mati: Jan 1878, Murton 1121 (SING [SING0230115]).

Note. The protologue consists of two plates labelled as Sindora wallichii and attributed to Bentham, on t. 1017 and t. 1018 respectively. However, only plate 1018 correctly depicts Sindora wallichii Benth. and t. 1017 shows Sindora echinocalyx Prain instead, as seen from the calyx of the flowers which are armed with long spines all over the exterior of the bud, rather than armed only on the upper half with small spines, as should be the case for Sindora wallichii.

ACKNOWLEDGEMENTS. The authors would like to thank Dr Richard Chung of the Forest Research Institute of Malaysia (FRIM) for facilitating a visit to KEP and for providing database records of Sindora specimens at KEP. We are also grateful to Dr Matti Niissalo, Paul Leong, Paul Parusuraman Athen, Lim Wei Hao and Koh Sin Lan for field work support. We would also like to thank the editor, Dr David Middleton, along with two anonymous reviewers for their constructive comments on this paper.

\section{References}

Bachman, S., Moat, J., Hill, A.W., de Torre, J. \& Scott, B. (2011). Supporting Red List threat assessment with GeoCAT: geospatial conservation assessment tool. ZooKeys 150: 117126.

Barstow, M. (2019a). Sindora coriacea. The IUCN Red List of Threatened Species 2019: e.T62027924A62027931. https://dx.doi.org/10.2305/IUCN.UK.2019-1.RLTS.T620279 24A62027931.en. Downloaded 9 Mar. 2020.

Barstow, M. (2019b). Sindora velutina. The IUCN Red List of Threatened Species 2019: e.T62027970A62027972. https://dx.doi.org/10.2305/IUCN.UK.2019-1.RLTS.T620279 70A62027972.en. Downloaded 9 Mar. 2020.

Bentham, G. (1867). Sindora wallichii Benth. In: Hooker, J.D. (ed.) Hooker's Icones Plantarum; or figures, with brief descriptive characters and remarks of new or rare plants, t. 1017. London: Williams \& Norgate.

Chen, D., Zhang, D. \& Hou, D. (2010). Sindora. In: Wu, Z.Y., Raven, P.H. \& Hong, D. (eds) Flora of China, vol. 10, Fabaceae, pp. 25-26. Beijing: Science Press; and St. Louis: Missouri Botanical Garden Press. 
Davison, G.W.H., Ng, P.K.L \& Ho, H.C. (2008). The Singapore Red Data Book: Threatened Plants and Animals of Singapore, 2nd edition. Singapore: Nature Society (Singapore).

De Wit, H.C.D. (1949). Revision of the genus Sindora Miquel (Legum.). Bull. Jard. Bot. Buitenzorg, ser. 3, 18: 5-82.

GBIF.org. (6 August 2020a). GBIF Occurrence Download (Sindora coriacea). https://doi. org/10.15468/dl.qg6rdu

GBIF.org. (6 August 2020b). GBIF Occurrence Download (Sindora echinocalyx). https://doi. org/10.15468/dl.fsrn78

GBIF.org. (6 August 2020c). GBIF Occurrence Download (Sindora siamensis). https://doi. org/10.15468/dl.tvppc8

GBIF.org. (6 August 2020d). GBIF Occurrence Download (Sindora velutina). https://doi. org/10.15468/dl.zgs 2 t6

GBIF.org. (6 August 2020e). GBIF Occurrence Download (Sindora wallichii). https://doi. org/10.15468/dl.qeqrev

Ho, B.C., Lua, H.K., Bazilah Ibrahim, Yeo, R.S.W., Athen, P., Leong, P.K.F., Ali Ibrahim, Koh, S.L., Hassan Ibrahim, Lindsay, S. et al. (2019). The plant diversity in Bukit Timah Nature Reserve, Singapore. Gard. Bull. Singapore 71(Suppl. 1): 41-134.

Hou, D. (1996). Sindora. In: Hou, D., Larsen, K. \& Larsen, S.S. (eds) Caesalpiniaceae. Flora Malesiana, ser. 1, Seed Plants, vol. 12, pt. 2, pp. 691-709. Leiden: Rijksherbarium.

IUCN (2012). IUCN Red List categories and criteria. Version 3.1. 2nd edition. Gland, Switzerland and Cambridge, UK: IUCN.

IUCN Standards and Petitions Subcommittee (2017). Guidelines for Using the IUCN Red List Categories and Criteria. Version 13. Prepared by the Standards and Petitions Subcommittee.

Prain, D. (1897). Order XXXVIII. Leguminosae. In: King, G. (ed.) Materials for a Flora of the Malayan Peninsula. J. Asiat. Soc. Bengal, Pt. 2, Nat. Hist. 66(1): 21-275.

Ridley, H.N. (1922). Sindora Miq. In: The Flora of the Malay Peninsula, vol. 1, Polypetalae, pp. 637-639. London: L. Reeve \& Co., Ltd.

Saw, L.G. (2010). Vegetation of Peninsular Malaysia. In: Parris, B.S., Kiew, R., Chung, R.C.K., Saw, L.G. \& Soepadmo, E. (eds) Flora of Peninsular Malaysia, ser. 2, Seed Plants, vol. 1, pp. 21-45. Malaysia: Forest Research Institute Malaysia.

Sosef, M.S.M. (1993). Sindora. Selection of Species. In: Soerianegara, I. \& Lemmens, R. (eds) PROSEA: Plant Resources of South-East Asia, vol. 5, pt. 1, Timber trees: Major commercial timbers, pp. 438-442. Leiden: Backhuys Publishers.

Symington, C.F. (1938). A note on certain Malayan species of Sindora. Bull. Misc. Inform. Kew 1938: 73-79.

Whitmore, T.C. (1972). Leguminosae. In: Whitmore, T.C. (ed) Tree Flora of Malaya, A Manual for Foresters, vol. 1, pp. 270-275. Kuala Lumpur: Longman Malaysia.

Wong, H.F., Tan, S.Y., Koh, C.Y., Siow, M.H.J., Li, T., Heyzer, A., Ang, A.H.F., Ismail, M., Srivathsan, A. \& Tan, H.T.W. (2013). Checklist of Plant Species of Nee Soon Swamp Forest, Singapore: Bryophytes to Angiosperms. Singapore: National Parks Board and Raffles Museum of Biodiversity Research, National University of Singapore. 